\title{
PAR1-Mediated NFrkB Activation Promotes Survival of Prostate Cancer Cells Through a Bcl-xL-Dependent Mechanism
}

\author{
Kwanchanit Tantivejkul, ${ }^{1}{ }^{*}$ Robert D. Loberg, ${ }^{1}$ Samkeliso C. Mawocha, ${ }^{1}$ Lashon L. Day, ${ }^{1}$ \\ Lauren St. John, ${ }^{1}$ Brian A. Pienta, ${ }^{1}$ Mark A. Rubin, ${ }^{2}$ and Kenneth J. Pienta ${ }^{1,3}$ \\ ${ }^{1}$ Department of Urology, The Michigan Urology Center, University of Michigan, \\ Ann Arbor, Michigan 48109 \\ ${ }^{2}$ Massachusettes General Hospital, Boston, Massachusettes \\ ${ }^{3}$ Department of Internal Medicine, Division of Hematology/Oncology, University of Michigan, \\ Ann Arbor, Michigan 48109
}

\begin{abstract}
We have previously reported that protease-activated receptor 1 (PAR1 or thrombin receptor) is overexpressed in metastatic prostate cancer cell lines compared to prostate epithelial cells. In this study, we examined 1,074 prostate biopsies by tissue microarray analysis and demonstrated that PAR1 expression is significantly increased in prostate cancer compared to normal prostate epithelial cells and benign prostatic hyperplasia. We hypothesized that PAR1 activation contributed to prostate cancer cell progression. We demonstrated that stimulation of PAR1 by thrombin or thrombin receptor activating peptide (TRAP6), in androgen-independent DU145 and PC-3 cells resulted in increased DNA binding activity of the NFKB p65 subunit. IL-6 and IL-8 levels were also elevated in conditioned media by at least two-fold within 4-6 h of PAR1 activation. This induction of cytokine production was abrogated by pretreatment of cells with the NFKB inhibitor caffeic acid phorbol ester. The $\mathrm{p} 38$ and ERK1/2 MAPK signaling cascades were also activated by PAR1 stimulation, whereas the SAPK/JNK pathway was unaffected. Inhibition of p38 and ERK1/2 by SB-203589 and PD098059, respectively, did not abrogate NFKB activity, suggesting an independent induction of NFKB by PAR1 stimulation. Furthermore, TUNEL assay showed that activation of PAR1 attenuated docetaxel induced apoptosis through the upregulation of the Bcl-2 family protein $\mathrm{BCl}-\mathrm{xL}$. Akt activation was not observed, suggesting that drug resistance induced by PAR1 was independent of PI3K signaling pathway. Because thrombin and PAR1 are over-expressed in prostate cancer patients, targeting the inhibition of their interaction may attenuate NFKB signaling transduction resulting in decreased drug resistance and subsequent survival of prostate cancer cells. J. Cell. Biochem. 96: 641-652, 2005. () 2005 Wiley-Liss, Inc.
\end{abstract}

Key words: prostate cancer; survival; PAR1; Bcl-xL; cytokines

The multifunctional serine protease thrombin is a key activator of the coagulation cascade and we have previously reported that proteaseactivated receptor 1 (PAR1 or thrombin receptor) is over-expressed in metastatic prostate cancer cell lines compared to prostate epithelial

Grant sponsor: US Army DOD; Grant number: DAMD 1701-1-0077; Grant sponsor: NIH; Grant number: NIH 1 PO1 CA093900-01A2.

*Correspondence to: Kwanchanit Tantivejkul, $\mathrm{PhD}$, Department of Urology, University of Michigan, 1500 E. Medical Center Drive, 7431 CCGC, Ann Arbor, MI 48109. E-mail: ktantive@umich.edu

Received 7 April 2005; Accepted 25 April 2005

DOI 10.1002/jcb.20533

(c) 2005 Wiley-Liss, Inc. cells. In addition to being responsible for platelet aggregation and converting fibrinogen to fibrin, thrombin also induces cellular responses such as proliferation and release of angiogenic factors [Zain et al., 2000; Huang et al., 2001; Maragoudakis et al., 2002]. Many patients with advanced cancer, including prostate cancer, suffer from thromboses due to excessive activation of the coagulation system [Kohli et al., 2002]. In many experimental systems, stimulation of cancer cells with thrombin is associated with modulation of cell adhesion, invasiveness, and metastasis [Nierodzik et al., 1992; Wojtukiewicz et al., 1993; Walz and Fenton, 1994].

Thrombin elicits cellular responses through the activation of a family of $\mathrm{G}$ protein-coupled protease-activated receptors (PARs) [Coughlin, 
1999]. Four known members of the PARs family have been identified: PAR1 and PAR3 are activated by thrombin, PAR2 is activated by trypsin, and PAR4 can be activated by both trypsin and thrombin [Vu et al., 1991]. The expression of PAR1 has been associated with tumor growth and increased metastasis [EvenRam et al., 2001; Yin et al., 2003]. Cleavage in the extended amino terminus of PAR1 by thrombin unmasks a new tethered ligand, which serves as an intramolecular activator. Thus, activation of PAR1 by thrombin is irreversible and can only be terminated by intracellular receptor recycling and degradation [Coughlin, 1999]. Identified signaling pathways that are activated by thrombin-mediated PAR1 activation include the phosphatidylinositol 3-kinase (PI3K) [Chalmers et al., 2003], protein kinase C [Lidington et al., 2000], c-Jun N-terminal kinase (JNK) [Mitsui et al., 1998], p38 MAPK [Marin et al., 2001], RhoGTPase [Ming et al.,

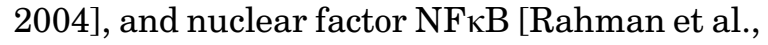
2002].

Previous reports have shown that the transcription factor $\mathrm{NF}_{\kappa} \mathrm{B}$ is constitutively active in androgen-insensitive prostate cancer cells [Palayoor et al., 1999; Suh et al., 2002; Zerbini et al., 2003]. Furthermore, tumor samples with high Gleason grades also have high nuclear expression of RelA (p65) [Suh et al., 2002]. $\mathrm{NF} \kappa \mathrm{B} / \mathrm{Rel}$ proteins regulate the expression of genes involved in cell growth and differentiation, inflammatory responses, and apoptosis. The NFкB/Rel proteins belong to two different classes distinguishable by their mode of synthesis and transactivation properties [Karin et al., 2002]. RelA (p65), RelB, and c-Rel are synthesized in their mature form, while p50/p105 $(\mathrm{NF} \kappa \mathrm{B} 1)$ and $\mathrm{p} 52 / \mathrm{p} 105(\mathrm{NF} \kappa \mathrm{B} 2)$ require proteolytic processing to produce mature DNA binding proteins. These proteins form various homoand hetero-dimers that exist in the inactive forms in the cytoplasm in complex with the

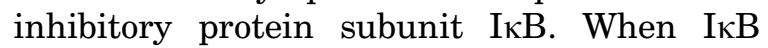
becomes phosphorylated by the I $\kappa \mathrm{B}$ kinase (I $\kappa \mathrm{K})$, it is marked for ubiquination and proteasomal degradation. Disassociation from I $\mathrm{I} B$ allows $N_{\kappa} \mathrm{B}$ to translocate to the nucleus. Subsequent phosphorylation facilitates binding to a specific DNA sequence, resulting in gene transcription.

Due to the fact that excessive amounts of thrombin are generated in prostate cancer patients and we and others have previously reported that PAR1 is upregulated in prostate cancer cell lines [Chay et al., 2002; Liu et al., 2003], we hypothesized that activation of PAR1 contributed to prostate cancer progression. We compared PAR1 expression in normal and cancerous prostate tissues and elucidated the function of PAR1 in prostate cancer by examining the effects of PAR 1 activation on signaling pathways including $\mathrm{NF} \kappa \mathrm{B}$ DNA binding activity, IкB phosphorylation, and MAPK signaling pathways. We also investigated the effects of PAR1 activation on cytokine productions and cell survival.

\section{MATERIALS AND METHODS}

\section{Tissue Microarray Analysis}

Immunohistochemistry of PAR1 expression was performed on prostate tissue microarrays (TMAs) as previously described [Rubin et al., 2002]. Standard biotin-avidin complex technique and a monoclonal antibody against PAR1 (Immunotech, Marseille, France) was used to evaluate PAR1 expression. Slides were counterstained with hematoxylin. Protein expression was scored as negative $($ score $=1)$, weak $($ score $=2)$, moderate (score $=3$ ), or strong (score $=4$ ) using a system that has been validated previously [Dhanasekaran et al., 2001]. Expression was graphically represented using error bars with 95\% confidence intervals. Differences between types of tissues were evaluated using ANOVA with a post hoc Scheffe analysis to take multiple tissue types into account.

\section{Cell Culture}

Human prostate cancer cell lines PC-3 and DU145 were obtained from ATCC (Manassas, VA). They were maintained in RPMI 1640 supplemented with $10 \%$ fetal bovine serum and $100 \mathrm{U} / \mathrm{ml}$ penicllin, $100 \mu \mathrm{g} / \mathrm{ml}$ streptomycin, and $250 \mathrm{ng} / \mathrm{ml}$ amphotericin B (all from Invitrogen, Carlsbad, CA) at $37^{\circ} \mathrm{C}$ in a $5 \% \mathrm{CO}_{2}$ humidified incubator. Stock solution of $1 \mu \mathrm{M}$ thrombin (Sigma, St. Louis, MO) and $6 \mathrm{mM}$ thrombin receptor activating peptide SFLLRN (TRAP6) (Bachem, King of Prussia, PA) were prepared in sterile distilled water and stored at $-20^{\circ} \mathrm{C}$.

\section{Cytosolic and Nuclear Protein Extraction}

Cells were collected in ice-cold PBS and pelleted by centrifugation at $400 \mathrm{~g}$ for $5 \mathrm{~min}$. Cells were lysed with ice-cold hypotonic lysis 
buffer (10 mM HEPES, pH 7.9; $1.5 \mathrm{mM} \mathrm{MgCl}$, $10 \mathrm{mM} \mathrm{KCl}, 0.5 \mathrm{mM}$ DTT, and $0.1 \%$ Triton $\mathrm{X}-100$ ) containing $1 \mu \mathrm{g} / \mathrm{ml}$ each of aprotinin, leupeptin and pepstatin A, $1 \mathrm{mM}$ PMSF, $1 \mathrm{mM}$ $\mathrm{NaF}$, and $1 \mathrm{mM} \mathrm{Na} \mathrm{VO}_{4}$. Cells were pelleted by centrifugation at 8,000g for $10 \mathrm{~min}$ and supernatant (cytosolic fraction) was snap-frozen immediately. The remaining cell pellet was incubated for $30 \mathrm{~min}$ on ice in nuclear extraction buffer (20 mM HEPES, pH 7.9, $1.5 \mathrm{mM} \mathrm{MgCl}_{2}$, $420 \mathrm{mM} \mathrm{NaCl}, 0.2 \mathrm{mM}$ EDTA, $0.5 \mathrm{mM}$ DTT, $1 \%$ Nonadet P-40, and $25 \% \mathrm{v} / \mathrm{v}$ glycerol) containing $1 \mu \mathrm{g} / \mathrm{ml}$ each of aprotinin, leupeptin and pepstatin A, $1 \mathrm{mM}$ PMSF, $1 \mathrm{mM} \mathrm{NaF}$, and $1 \mathrm{mM}$ $\mathrm{Na}_{3} \mathrm{VO}_{4}$. Nuclear suspension was centrifuged at $16,000 \mathrm{~g}$ for $5 \mathrm{~min}$ and nuclear extract was snapfrozen immediately. Protein concentrations were determined by Biorad protein determination reagent (Biorad, Hercules, CA).

\section{NFкB Transcription Factor Assay}

The $\mathrm{NF}_{\kappa} \mathrm{B}$ transcription factor assay kits (Chemicon International, Temecula, CA) were used to quantitate nuclear activation of unstimulated and PAR1-stimulated cells. Nuclear extracts were incubated with $\mathrm{NF} \kappa \mathrm{B}$ capture probe for $1 \mathrm{~h}$ at room temperature. Contents were then transferred to an ELISA plate and incubated for $1 \mathrm{~h}$ more at room temperature. Plates were washed and each well was incu-

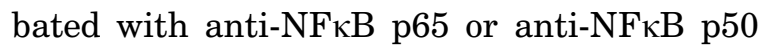
antibodies followed by anti-rabbit IgG-HRP conjugated secondary antibody. Bound $\mathrm{NF}_{\kappa} \mathrm{B}$ components were detected by chemiluminescent detection reagent and absorbance was measured with a microplate luminometer (Molecular Devices, Sunnyvale, CA).

\section{Cytokine ELISA Assays}

Cells at $60 \%-80 \%$ confluency were plated in 6-well plates and starved for $2 \mathrm{~h}$ prior to treatment with thrombin or TRAP6 in serumfree RPMI 1640 supplemented with $1 \%$ penicillin and streptomycin. Conditioned medium from each well was collected at various time points and stored at $-20^{\circ} \mathrm{C}$ until use. IL- 6 expression in cell culture supernatants was determined by using ChemiKine ${ }^{\mathrm{TM}}$ human IL-6 sandwich ELISA kit (Chemicon International, Temecula, CA) and IL-8 expression was determined by using Quantikine human IL-8 immunoassay kit (R\&D Systems, Minneapolis, MN) according to the protocols supplied by the manufacturers.

\section{TUNEL Staining}

Cells were seeded in chamber slides to $60 \%-$ $80 \%$ confluency. They were starved for $2 \mathrm{~h}$ and stimulated with either thrombin or TRAP6 in serum-free RPMI 1640 supplemented with 1\% penicillin and streptomycin for $4 \mathrm{~h}$ prior to addition of $100 \mathrm{nM}$ taxotere overnight. Cells were then fixed in freshly prepared $4 \%$ parafolmaldehyde in PBS, $\mathrm{pH}$ 7.4. After blocking with $3 \% \mathrm{H}_{2} \mathrm{O}_{2}$ in methanol, cells were permeabilized with $0.1 \%$ Triton $\mathrm{X}-100$ in $0.1 \%$ sodium citrate. They were then labeled with TUNEL reaction mixture (Roche, Indianapolis, IN) for $1 \mathrm{~h}$ at $37^{\circ} \mathrm{C}$ in a humidified atmosphere in the dark. DAPI was used to visualize the nucleus. Samples were analyzed under a fluorescence microscope at $450 \mathrm{~nm}$ excitation and $565 \mathrm{~nm}$ emission.

\section{Western Blot and Immunoblotting}

Cells were lysed in RIPA buffer (50 mM Tris$\mathrm{HCl}, \mathrm{pH} 7.4,1 \% \mathrm{NP}-40,150 \mathrm{mM} \mathrm{NaCl}, 1 \mathrm{mM}$ EDTA, $1 \mathrm{mM}$ PMSF, $1 \mathrm{mM} \mathrm{Na} \mathrm{VO}_{4}, 1 \mathrm{mM} \mathrm{NaF}$, $1 \mu \mathrm{M}$ okadaic acid, and $1 \mu \mathrm{g} / \mathrm{ml}$ each of aprotinin, leupeptin, and pepstatin). Proteins were separated in 10\%-15\% SDS-PAGE gels and transferred onto PVDF membrane. Membranes were blocked with $5 \%$ milk in PBST $(0.1 \%$ Tween in PBS) for $1 \mathrm{~h}$ at room temperature. They were incubated overnight at $4^{\circ} \mathrm{C}$ with primary antibodies: anti-phospho p38 (Thr180/Tyr182), anti-phospho ERK1/2 (Thr202/Tyr204), antiphospho SAPK/JNK (Thr183/Tyr185), antiphospho ATF-2, anti-phospho Akt (Ser473), anti-Akt, anti-phospho GSK3 $\alpha / \beta$ (Ser21/9), anti-GSK3 $\beta$, anti-phospho $\mathrm{I} \kappa \mathrm{B}$, anti-IкB, anti$\mathrm{NF} \kappa \mathrm{B}$, anti-Bcl-xL, anti-Bcl2, anti-survivin, anti-Bad, anti-Mcl-1, and anti-actin (all from Cell Signaling Technology, Beverly, MA). Membranes were washed three times prior to incubation with secondary antibodies (HRPconjugated anti-rabbit from Cell Signaling Technology or HRP-conjugated anti-mouse from Santa Cruz Biotechnology, Santa Cruz, $\mathrm{CA}$ ) for $1 \mathrm{~h}$ at room temperature. Bands were visualized by ECL chemiluminescent (Promega, Madison, WI) and quantitated using Image $\mathbf{J}$ software (NCI, Bethesda, MD).

\section{Statistical Analysis}

Results obtained from each experiment are expressed as mean \pm standard deviation of triplicates. To perform statistical analysis, the 
two-tailed Student's $t$-test was used; a $p$ value less than 0.05 is considered significant.

\section{RESULTS}

\section{PAR1 Is Overexpressed in Prostate Cancer}

Over-expression of PAR1 has been previously reported in human prostate cancer cell lines [Chay et al., 2002; Liu et al., 2003]. Tissue microarray of 1,074 samples collected from normal prostate, benign prostatic hyperplasia $(\mathrm{BPH})$, prostatic intraepithelial neoplasia (PIN), cancerous prostates, and metastatic lesions revealed that PAR1 expression increased proportionately to the degree of prostate disease (Fig. 1). BPH expressed higher levels of PAR1 than normal prostate stroma (BPH $1.4 \pm 0.1$, stroma $1.1 \pm 0.2$ stain intensity). Tissues from high grade PIN and prostate adenocarcinoma exhibited significantly higher magnitude of PAR1 expression compared to normal prostate stroma, BPH, and atrophic prostate tissues (PIN 2.7 \pm 0.2 , prostate cancer $2.5 \pm 0.1$ stain intensity, respectively), suggesting that upregulation of PAR 1 is an early event in prostate tumorigenesis.

\section{Stimulation of PAR1 Activates NFкB Signal Transduction}

To elucidate the significance of PAR1 signaling in prostate cancer cells, we performed transcription factor activation assay using nuclear protein extracts to evaluate $\mathrm{NF} \kappa \mathrm{B}$ DNA binding activity. We used two androgeninsensitive cell lines which have high (PC-3 cells) and low levels (DU145 cells) of PAR1 expression [Chay et al., 2002]. Cells were stimulated with 2 and $10 \mathrm{nM}$ thrombin (physiological

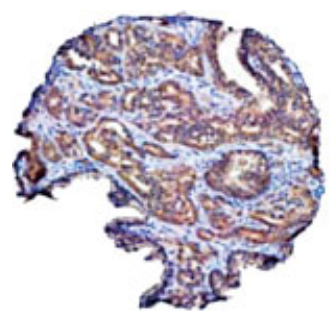

Normal Prostate

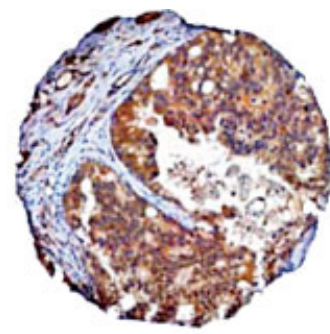

High Grade PIN

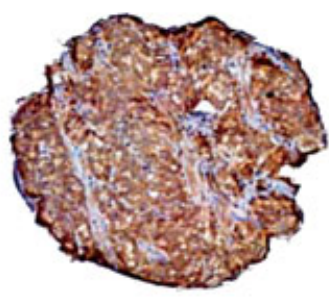

Prostate Adenoca

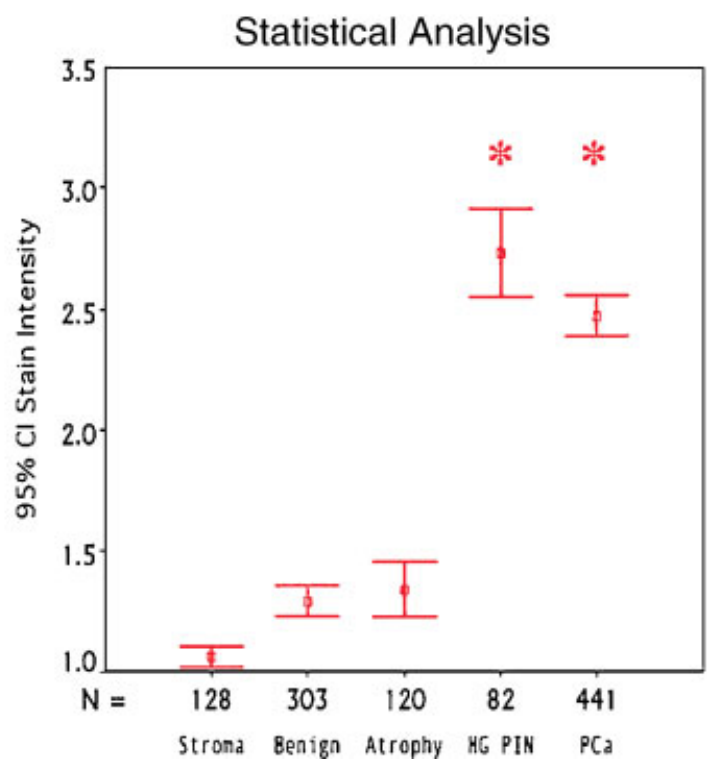

Fig. 1. PAR 1 expression increases in prostate cancer. An analysis of 1,074 samples showed a significant increase in PAR1 expression in high grade PIN and prostate cancer compared to normal prostate stroma, benign prostate hypertrophy, and atrophic prostate tissue. Representative TMA images of normal prostate, high grade PIN, and prostate adenocarcinoma stained with PAR1 monoclonal antibody and counterstained with hematoxylin are shown. Slides were scored as described in "Materials and Methods." The graph represents scored PAR1 expression $\pm 95 \%$ confidence intervals. 
and pharmacological concentration, respectively), and 20 and $100 \mu \mathrm{M}$ TRAP6, a PAR1specific activator, for $30 \mathrm{~min}$. The result demonstrated no change in $\mathrm{NF} \kappa \mathrm{B}$ p50 subunit DNA binding activity in both DU145 and PC-3 cells (Fig. 2A,B). However, TRAP6 stimulation of DU145 cells resulted in two-fold increase of $\mathrm{NF} \kappa \mathrm{B}$ p65 subunit DNA binding activity. Dosedependent increase of p65 subunit in PC-3 cells was also observed after PAR1 stimulation with either thrombin (1.5-fold increase with $2 \mathrm{nM}$ thrombin and 1.8-fold increase with $10 \mathrm{nM}$ thrombin) or TRAP6 (two-fold increase with $20 \mu \mathrm{M}$ TRAP6 and 3.1-fold increase with $100 \mu \mathrm{M}$ TRAP6, $p<0.01$ ). To confirm that NF $\kappa$ B was activated, we also analyzed phosphorylation
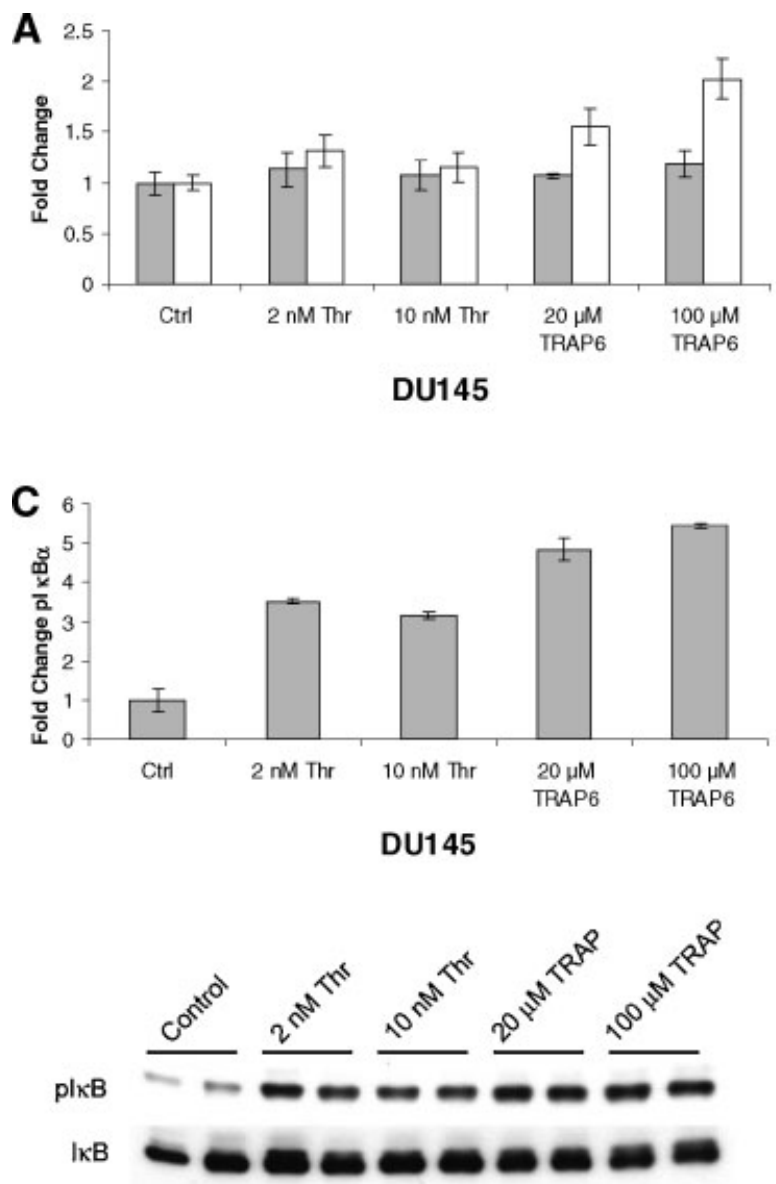

Fig. 2. Stimulation of PAR1 specifically activates NFkB p65 subunit transcription factor activation in prostate cancer. Transcription factor assays were used to assess DNA binding activity of the p50 (gray bars) or p65 (white bars) subunits in the nuclear extracts of DU145 and PC-3 cells stimulated with thrombin (Thr) or TRAP6 for $30 \mathrm{~min}(\mathbf{A}, \mathbf{B}, *, p<0.05)$. Each experiment was performed in triplicate and the result expressed as mean \pm standard deviation. Cytosolic extracts $(15 \mu \mathrm{g})$ were separated on $10 \%$ SDS gels and immunoblotted for ІкB status of IкB by Western blot analysis of the cytosolic protein extracts (Fig. 2C,D). DU145 cells demonstrated a three- to five-fold increase in $\mathrm{I} \kappa \mathrm{B}$ phosphorylation when stimulated with thrombin or TRAP6. Treatment of PC-3 cells with thrombin increased I $\mathrm{B}$ phosphorylation by two- to three-fold compared to untreated control cells $(p<0.05)$, whereas TRAP6 induced 5.7- to 8-fold increase in I $\mathrm{B}$ phosphorylation $(p<0.01)$. Since IкB phosphorylation releases $\mathrm{NF} \kappa \mathrm{B}$ for translocation into the nucleus, the result supported our findings that stimulation of PAR1 increased NF $\kappa$ B DNA binding activity in prostate cancer cells.

To evaluate the extent of NF $\mathrm{NB}$ activity induced through PAR1, we examined the production
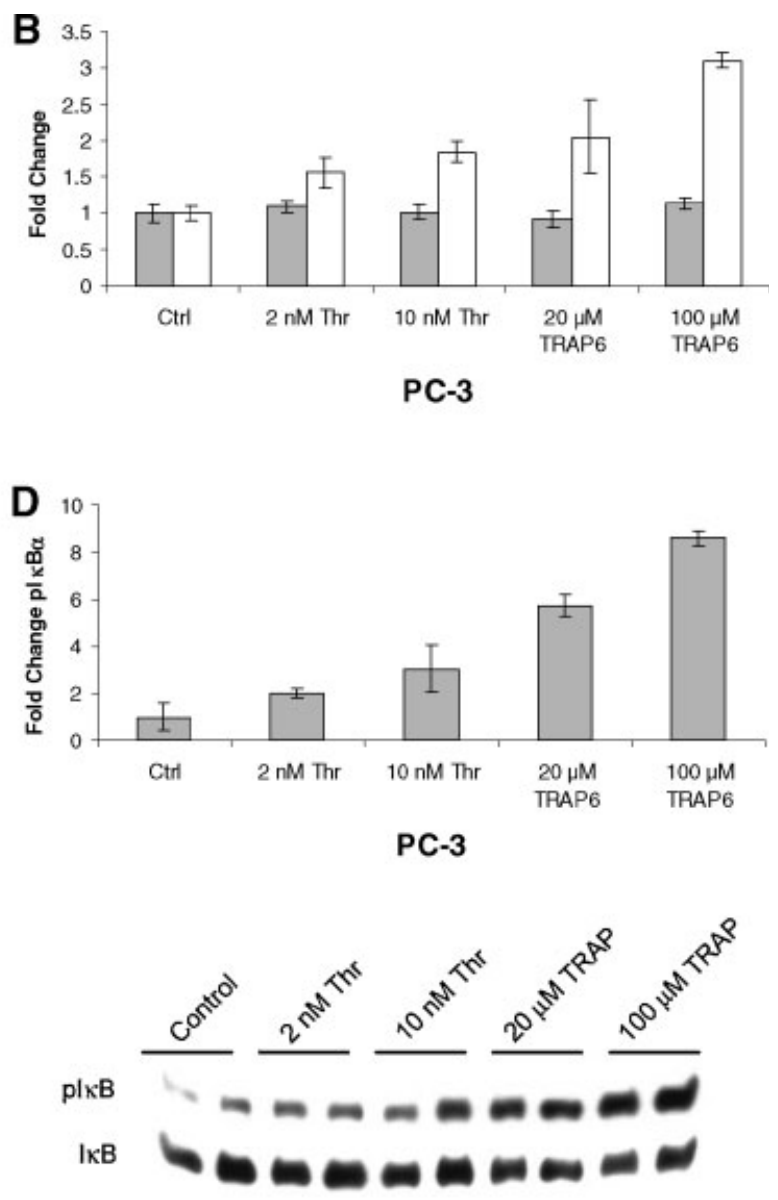

phosphorylation (C, D). The membranes were stripped and reprobed for total $\mathrm{I} \mathrm{KB}$ expression and the ratio of $\mathrm{I} \mathrm{KB}$ phosphorylation to total І $\mathrm{K}$ B expression was obtained by analyzing signal intensity of autoradiographic bands. Changes in I $\mathrm{KB}$ phosphorylation were quantitated as fold change compared to untreated control. Each experiment was performed in duplicate and the result expressed as mean \pm standard deviation. 
of IL-6 and IL-8 cytokines by ELISA. Conditioned media collected over a $24 \mathrm{~h}$-period from cells that have been treated with or without thrombin or TRAP6 was used to quantify IL-6 and IL-8 levels. Our result showed that DU145 constitutively produced less IL-6 and IL-8 than PC-3 cells. Conditioned media of DU145 cells collected after $24 \mathrm{~h}$ of incubation contained $41.7 \pm 1.5 \mathrm{pg} / \mathrm{ml} \mathrm{IL-6}$ and $258.6 \pm 21.1 \mathrm{pg} / \mathrm{ml}$ IL-8 compared to $230.4 \pm 67.5 \mathrm{pg} / \mathrm{ml}$ IL-6 and $24675 \pm 3914 \mathrm{pg} / \mathrm{ml}$ IL-8 produced by PC-3 cells (Fig. 3). However, within 4-6 h of stimulation with thrombin or TRAP6, IL-6 and IL-8 levels increased by at least two to six-fold in DU145 cells (Fig. 3A,C). This increase in cytokine production was maintained over the $24 \mathrm{~h}$ period. Similarly, thrombin and TRAP6 also induced PC-3 cells to increase IL-8 production by as much as eight-fold within $8 \mathrm{~h}$ (Fig. 3B,D). Furthermore, cytokine production induced by PAR1 stimulation was abrogated when cells were pretreated with CAPE $(50 \mu \mathrm{g} / \mathrm{ml})$, an inhibitor of $\mathrm{NF} \kappa \mathrm{B}$ activity, suggesting that cytokine production was dependent on $\mathrm{NF} \kappa \mathrm{B}$ activation (Fig. 4).

\section{MAPKs Are Activated by PAR1 Stimulation}

$\mathrm{NF} \kappa \mathrm{B}$ signal transduction in prostate cancer has been shown to be regulated by the MAPK signaling pathway [Je et al., 2004]. Here we investigated PAR1-mediated phosphorylation and activation of p38, ERK1/2, and SAPK/JNK MAP kinase signaling cascades by Western blot analysis. DU145 and PC-3 cells stimulated with thrombin or TRAP6 for $30 \mathrm{~min}$ resulted in a significant increase in p38 and ERK1/2 phosphorylation compared to untreated control cells (Fig. 5). SAPK/JNK phosphorylation remained unaffected in both DU145 and PC-3 cells by PAR1 stimulation. Furthermore, phosphorylation of pMAPKAPK2, a downstream mediator of p38 and ERK1/2 signaling, was induced by 30 min stimulation with $10 \mathrm{nM}$ thrombin and $100 \mu \mathrm{M}$ TRAP6. Additionally, phosphorylation of HSP27 and ATF-2 was induced by PAR1 stimulation in both DU145 and PC-3 cells.

It has been reported that inhibition of $\mathrm{p} 38$ by MAPK inhibitor in endothelial cells reduced ATF-2 activity, thereby suppressing $\mathrm{NF}_{\kappa} \mathrm{B}$ nuclear translocation [Kaur et al., 2003]. To determine whether PAR1-induced $\mathrm{NF} \kappa \mathrm{B}$ activation was dependent on MAPK activity, we treated DU145 and PC-3 cells with TRAP6 ( $100 \mu \mathrm{M}$ for $30 \mathrm{~min}$ ) in the presence and absence of a p38 (SB-203589) or ERK1/2 (PD-098059) inhibitor. Neither inhibitor suppressed TRAP6induced p65 subunit DNA binding activity in DU145 or PC-3 cells, suggesting that NF $\kappa \mathrm{B}$ activation through PAR1 is independent of the p38 and ERK1/2 activities (Fig. 6).
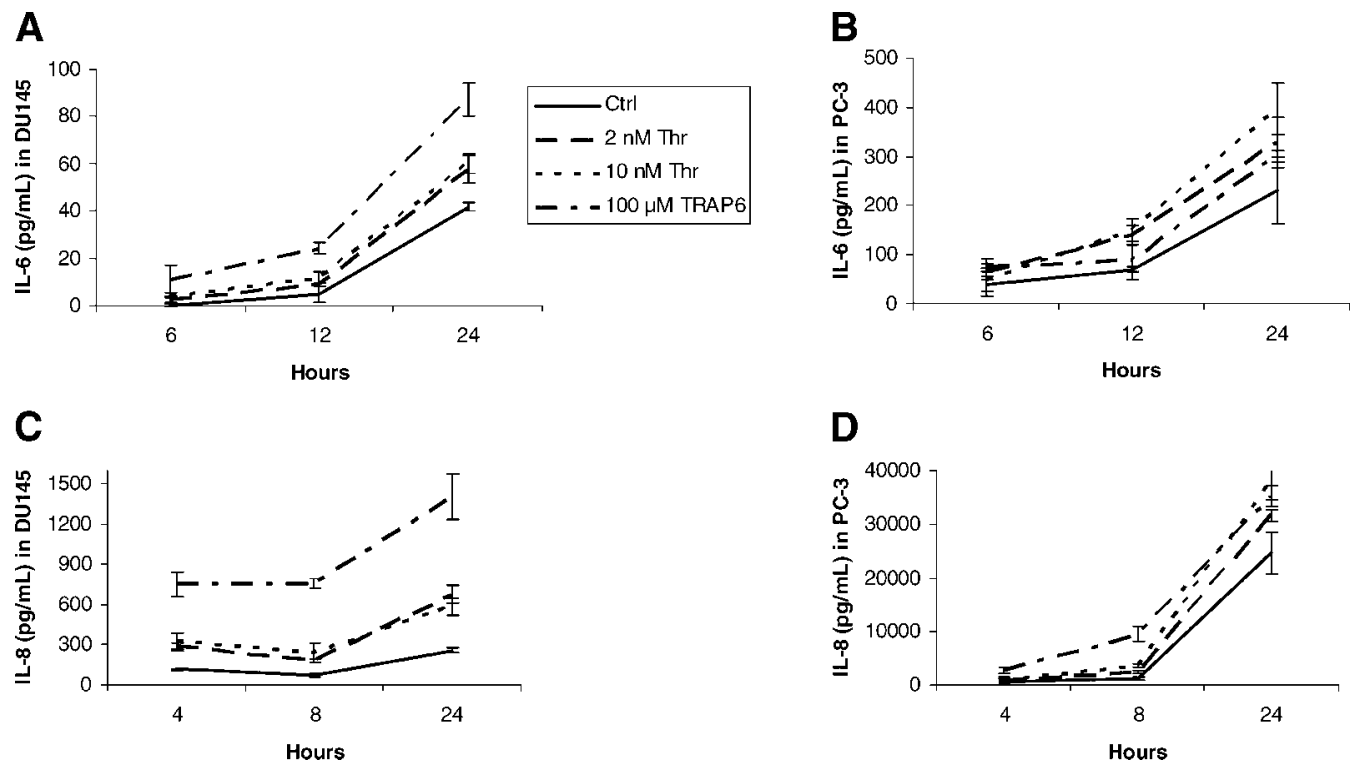

Fig. 3. PAR1 activation stimulates cytokine productions in prostate cancer cells. The amount of IL-6 (A, B) and IL-8 $($ C, D $)$ produced by DU145 and PC- 3 cells $\left(5 \times 10^{5}\right.$ cells per well) treated or untreated with thrombin (Thr) or TRAP6 was measured by ELISA as described in "Materials and Methods." Conditioned media was collected at the indicated time points and kept frozen at $-20^{\circ} \mathrm{C}$ until the assay was performed. Each data point represents the mean \pm standard deviation of three separate samples. 


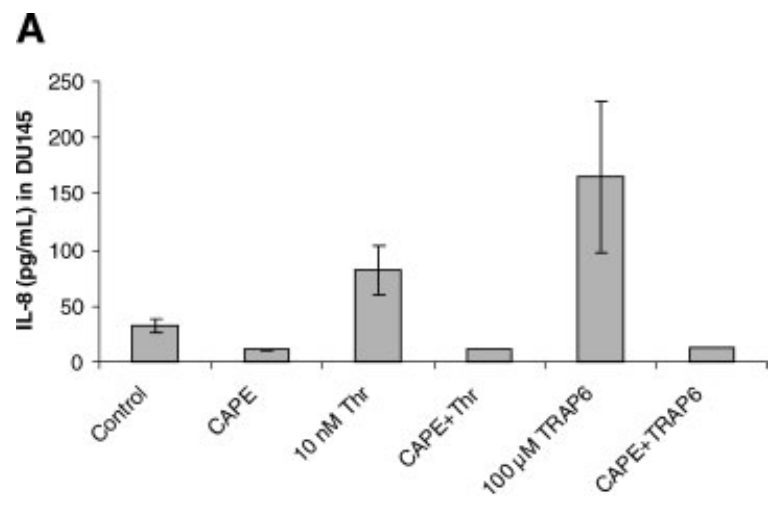

B

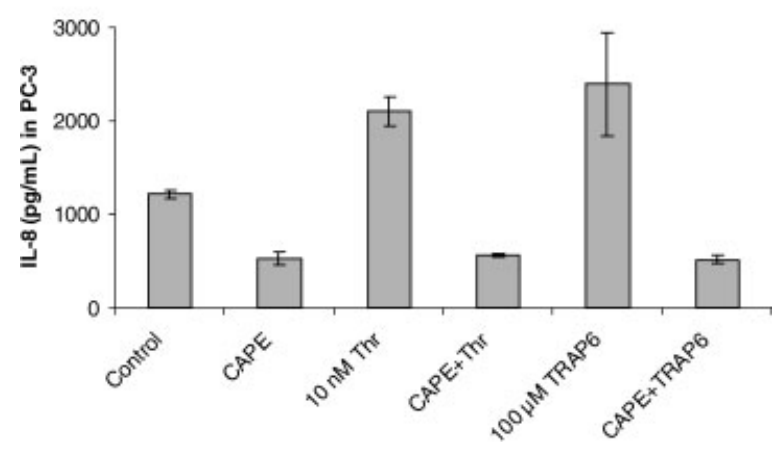

Fig. 4. Inhibition of $N F \kappa B$ abrogates PAR1-induced cytokine secretion. DU145 (A) and PC-3 (B) cells were pretreated with $50 \mu \mathrm{g} / \mathrm{ml}$ caffeic acid phorbol ester (CAPE), a specific NFKB inhibitor, for $1 \mathrm{~h}$ followed by the addition of $10 \mathrm{nM}$ thrombin (Thr) or $100 \mu \mathrm{M}$ TRAP6. After $8 \mathrm{~h}$ of incubation, conditioned media was collected and the amount of IL-8 produced in culture of was measured. Each data point represents the mean \pm standard deviation of three separate samples.

\section{Suppression of Docetaxel-Induced Apoptosis}

To investigate the functional significance of PAR1 activation, we used docetaxel to induce apoptosis. DU145 cells were pretreated with 10 $\mathrm{nM}$ thrombin or $100 \mu \mathrm{M}$ TRAP6 for $4 \mathrm{~h}$ prior to the addition of $100 \mathrm{nM}$ docetaxel overnight. Apoptotic cells were identified by TUNEL staining of the nucleus (Fig. 7). Untreated control, thrombin-treated or TRAP6-treated cells did not have cells undergoing apoptosis. Docetaxel induced apoptosis in approximately $20 \%$ of cells as evident by positive TUNEL staining. However, pretreatment of prostate cancer cells with either thrombin or TRAP6 suppressed docetaxel-induced apoptosis. Similar results were observed in PC-3 cells (data not shown).

To determine the mechanism by which PAR1 stimulation inhibited apoptosis, we examined the expression levels of Bcl-2 family member proteins by Western blot. Cells were treated with thrombin or TRAP6 for $4 \mathrm{~h}$ and total cell lysates were collected for analysis (Fig. 8). In both cell lines, treatment with thrombin or TRAP6 induced the upregulation of Bcl-xL expression. Mcl-1, which is constitutively expressed in DU145 but not PC-3 cells was also upregulated by PAR1 stimulation in DU145 cells. No significant change was detected in the expressions of Bcl-2, Bad, and survivin in either DU145 or PC-3 cells. To investigate whether PI3K was involved in PAR1-induced survival, we examined the phosphorylation state of Akt and Gsk $3 \alpha / \beta$. No difference in the phosphorylation of Akt or Gsk3 $\alpha / \beta$ was observed when cells were treated with thrombin or TRAP6 for 30 min, suggesting that PI3K is not involved.

\section{DISCUSSION}

There is no curative treatment for metastatic prostate cancer. We have previously reported that PAR1 is over-expressed in metastatic prostate cancer cell lines compared to normal prostate epithelial cells [Chay et al., 2002]. We hypothesized that PAR1 over-expression could contribute to prostate cancer cell progression and survival. In this study, we examined tissue expression of PAR1 from over 1,000 tissue samples collected from prostate biopsies. We demonstrated that PAR1 over-expression is evident early in tumorigenesis. Previous studies have also shown that men with advanced prostate cancer tend to have elevated thrombin levels [Lind et al., 2003]. Due to the fact that thrombin and its receptor, PAR1, are present in high levels in prostate cancer patients, we investigated the role of PAR1 stimulation by thrombin or TRAP6, a PAR1-specific activator. We report here that PAR 1 activation leads to $\mathrm{NF} \kappa \mathrm{B}$ signal transduction which resulted in increased cell resistance to docetaxel-induced apoptosis, via a Bcl-xL dependent mechanism.

$\mathrm{NF} \kappa \mathrm{B}$ is known to play an important role in the control of cell growth, differentiation, survival, and cytokine productions. It has been shown that activation of $\mathrm{NF} \kappa \mathrm{B}$ through stimuli such as TGF $\beta 2$ or lysophosphatitidic acid promotes prostate cancer cell survival [Lu et al., 2004; Raj et al., 2004]. We used two androgen-insensitive cell lines that differ in the levels of PAR1 expression: PC-3 cells which have high PAR1 expression compared to DU145 


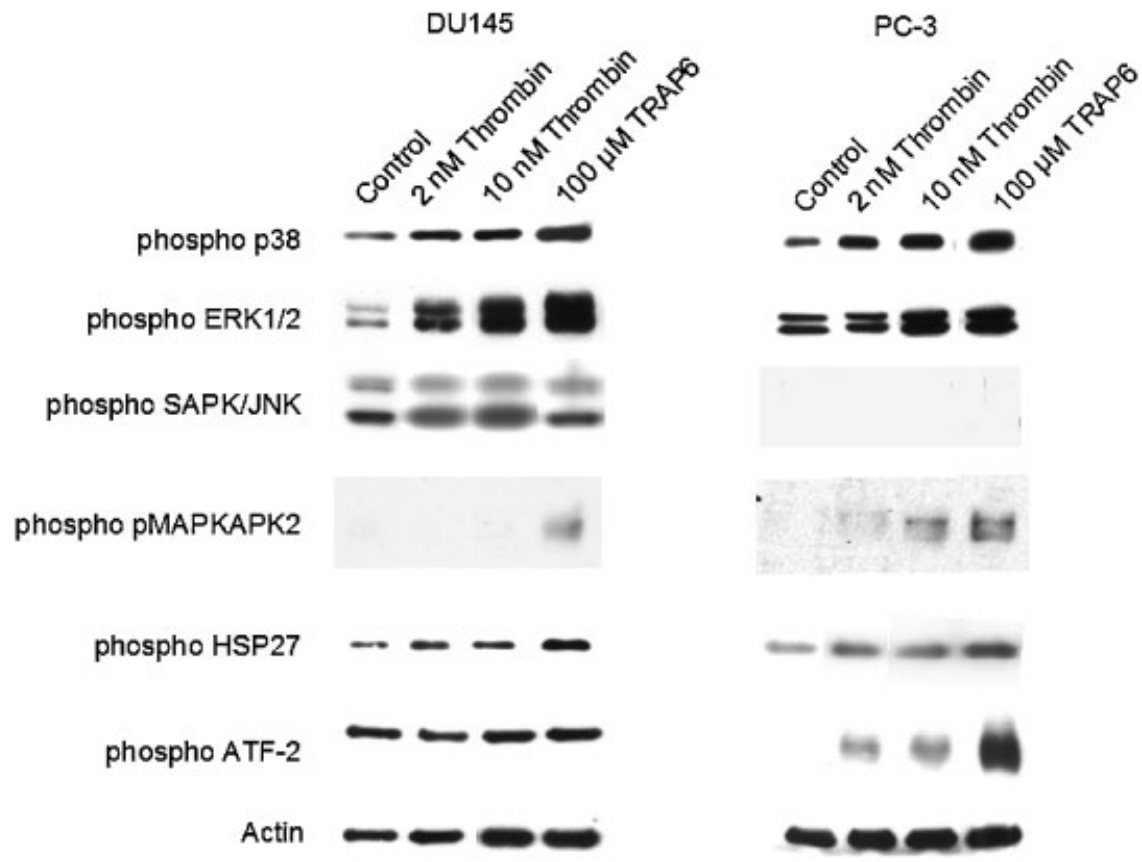

Fig. 5. Activation of PAR 1 leads to activation of $\mathrm{p} 38$ and Erk1/2 MAPK signaling pathways. Total cell lysates ( $40 \mu \mathrm{g} /$ lane) were separated by $12.5-15 \%$ SDS-PAGE and proteins were analyzed by chemiluminescence.

A

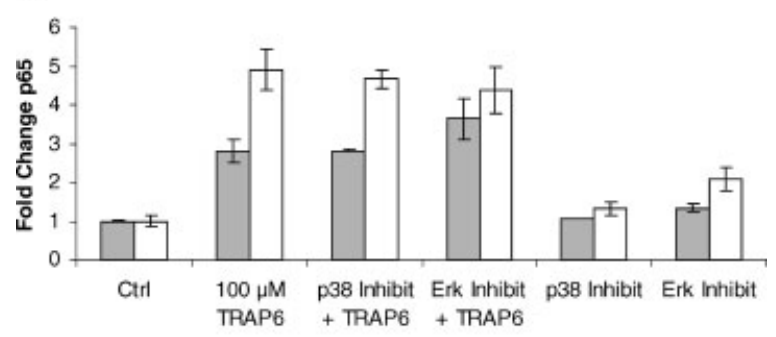

B

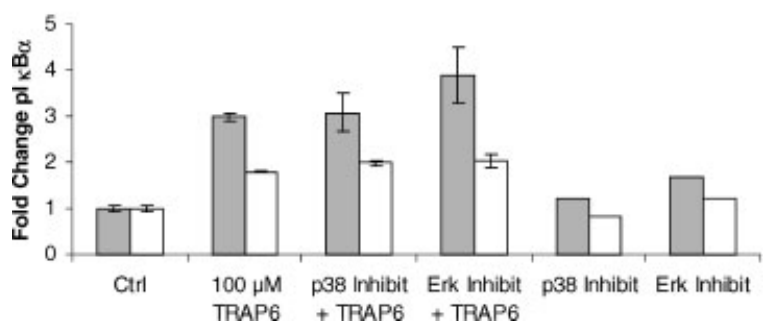

Fig. 6. MAPK inhibitors do not suppress NFKB activation by TRAP6 in prostate cancer cells. Cells were pretreated with p38 inhibitor (SB-203589) and Erk1/2 inhibitor (PD-098059) for 30 min prior to stimulation with $100 \mu \mathrm{M}$ TRAP6 for an additional $30 \mathrm{~min}$. Nuclear fraction was collected from DU145 (gray bars) and PC-3 (white bars) cells (A). NFkB p65 subunit transcription factor activation was measured as previously described. Cytosolic protein extracts ( $15 \mu \mathrm{g} /$ lane) were analyzed for I $\mathrm{I} B$ phosphorylation status $(\mathbf{B})$. Each experiment was performed in duplicate and the result expressed as mean \pm standard deviation. cells which have low PAR1 expression. We showed that stimulation of both prostate cancer cell lines by thrombin or TRAP6 increased $\mathrm{NF} \kappa \mathrm{B}$ p65 subunit activation. In a study of benign and malignant human prostate tissues, Shukla et al. [2004] reported that NFкB p65 subunit, but not the p50 subunit, is constitutively activated in human prostate cancer. Although constitutive activation of the $\mathrm{NF} \kappa \mathrm{B}$ p50 subunit has been shown to be critical in mouse skin carcinogenesis model [Budunova et al., 1999], it is less abundant and has a lower transcriptional activity than the $\mathrm{NF} \kappa \mathrm{B}$ p65 subunit [Karin et al., 2002]. We did not see a significant change in p50 subunit activity with thrombin or TRAP6 stimulation, possibly due to the low levels present in these cells.

Constitutive expression of IL-6 in androgenindependent prostate cancer cell lines has been reported [Zerbini et al., 2003]. Our results demonstrated that DU145 cells produced significantly lower amounts of IL- 6 and IL-8 than PC-3 cells under serum-depleted conditions. However, upon stimulation with thrombin or TRAP6, prostate cancer cells increased IL-6 and IL- 8 productions by at least two-fold over untreated control cells within 4-6 h. The induction of IL- 6 and IL-8 through PAR1 may play a key role in prostate cancer progression. 


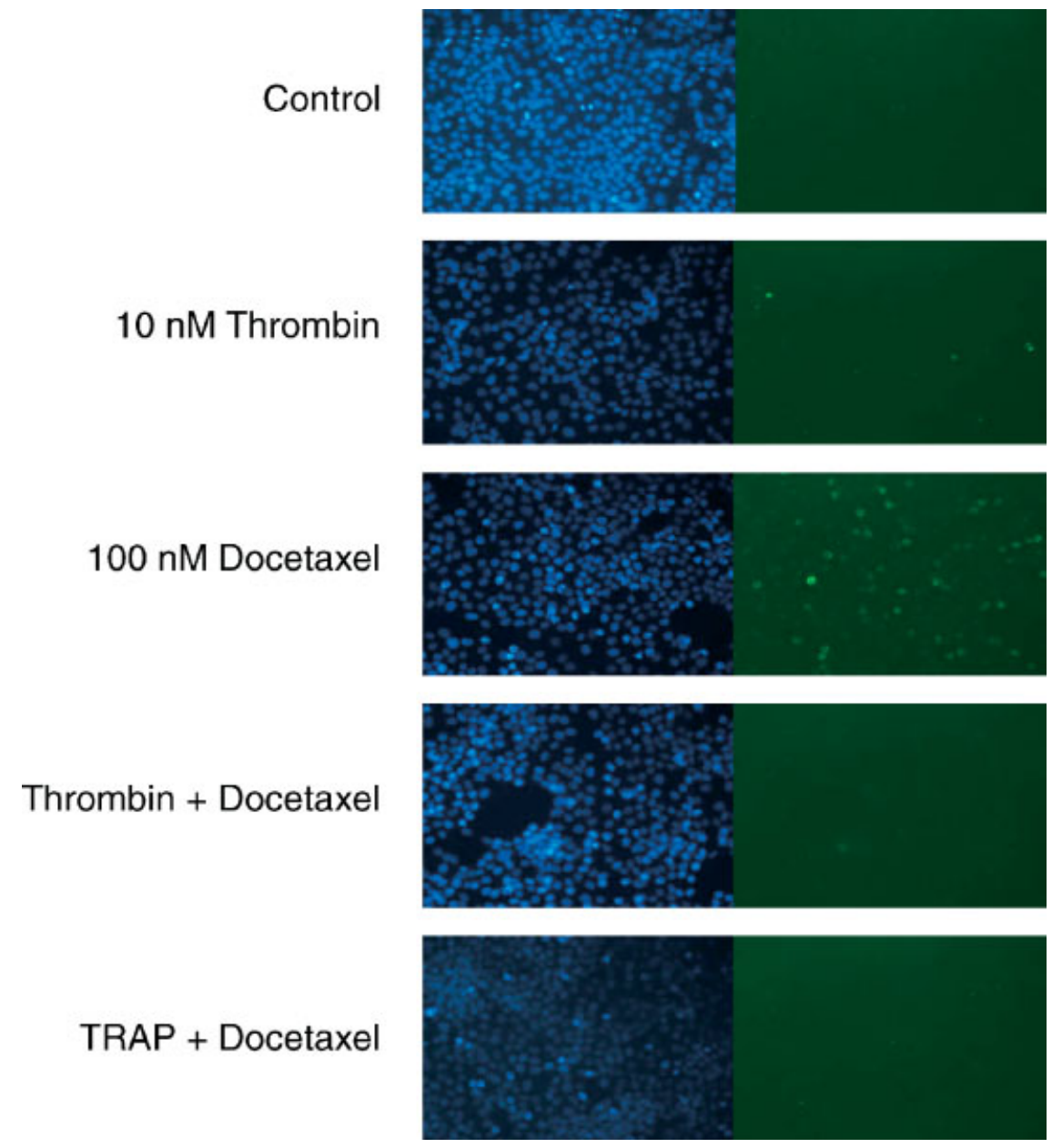

Fig. 7. TUNEL assay showed that thrombin or TRAP6 suppressed docetaxel-induced apoptosis. DU145 cells were pretreated with thrombin or TRAP6 for $4 \mathrm{~h}$ followed by induction of apoptosis with $100 \mathrm{nM}$ docetaxel. After incubation overnight, the slides were fixed and labeled with TUNEL labeling reagent (right panel) and DAPI (left panel) for nuclear morphology. The experiment was repeated three times.

Evidence suggests that IL-6 acts as a survival factor in tumors such as multiple myeloma [Hardin et al., 1994], esophageal carcinoma [Leu et al., 2003], and colon cancer [Yuan et al., 2004]. In prostate cancer, introduction of exogenous IL-6 conferred resistance to cytotoxic agent-induced apoptosis [Pu et al., 2004]. Furthermore, IL-8 has been shown to contribute to the development of benign prostate hyperplasia by stimulating growth of both benign prostate epithelial cells and stromal cells [Castro et al., 2004]. Orthotopic implantation of a PC-3 cell clone that highly produces IL-8 into nude mice resulted in highly tumorigenic and vascularized prostate tumor compared to low IL-8 producing clone [Kim et al., 2001]. We demonstrated that these cytokines are under the control of $\mathrm{NF} \kappa \mathrm{B}$ and can be regulated by
PAR1 activation. Suppression of $\mathrm{NF} \kappa \mathrm{B}$ activity by its inhibitor CAPE suppressed IL-6 (data not shown) and IL-8 productions in prostate cancer cells, suggesting an important mechanism of $\mathrm{NF} \kappa \mathrm{B}-$ mediated survival.

$\mathrm{NF} \kappa \mathrm{B}$ signal transduction in prostate cancer has been shown to be regulated by the p38 MAPK signaling pathway [Shimada et al., 2003; Je et al., 2004]. In platelets, activation of p38 by thrombin leads to $\mathrm{NF} \kappa \mathrm{B}$-dependent leukocyte recruitment [Kaur et al., 2003]. In macrophages, all three MAPK signaling pathways were activated by thrombin [Kang et al., 2003]. However, our results indicated that $\mathrm{NF}_{\kappa} \mathrm{B}$ activation via PAR1 is independent of the MAPK signaling pathways. Nonetheless, PAR1 activation resulted in the activation of p38 and ERK1/2 signaling cascades, whereas the SAPK/ 
A

DU145

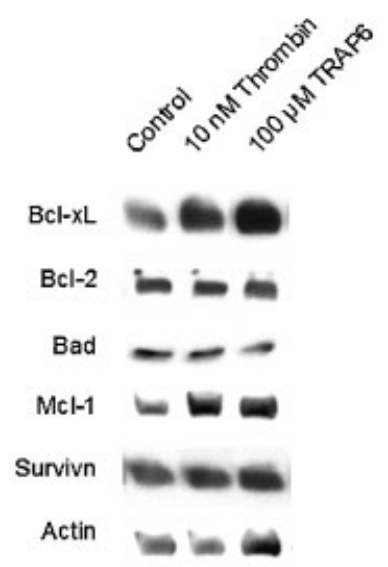

B

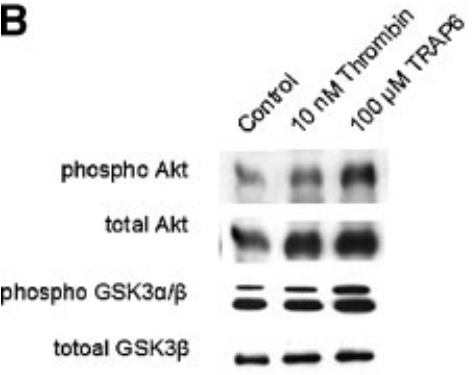

PC-3
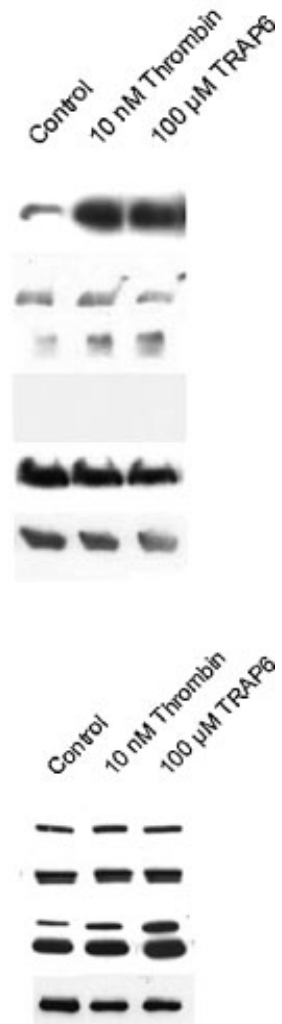

Fig. 8. PAR1 stimulation protects prostate cancer cells from apoptosis through the Bcl-2 family proteins, but not Akt. Cells were serum-starved for $2 \mathrm{~h}$ followed by stimulation with $10 \mathrm{nM}$ thrombin or $100 \mu \mathrm{M}$ TRAP6 for $4 \mathrm{~h}$. Proteins from cell lysates (40 $\mu \mathrm{g} /$ /ane) were collected and separated on $12.5-15 \%$ SDS gels and probed for $\mathrm{BCl}-\mathrm{xL}, \mathrm{BCl}-2, \mathrm{Bad}, \mathrm{Mcl}-1$, survivin, and actin (A). Anti-phospho Akt and anti-phospho Gsk3 $\alpha / \beta$ were used to detect Akt and Gsk3 $\alpha / \beta$ activation status (B). Membranes were then stripped and rehybridized to detect total expression of Akt and Gsk3 $\alpha / \beta$. Each experiment was performed in duplicate and repeated three times.

JNK pathway was unaffected. It is possible that p38, ERK1/2, and $N F \kappa B$ are all required for the survival of prostate cancer cells and that PAR1dependent $\mathrm{NF} \kappa \mathrm{B}$ activation is regulated by alternative mechanisms.

Activation of the PI3K signaling cascade has long been considered a crucial pathway of cell survival, and the loss of the tumor suppressor gene PTEN function and expression in prostate cancer has been well-characterized [Deocampo et al., 2003; Koksal et al., 2004]. The loss of PTEN, a negative regulator of PI3K, leads to the dysregulation of PI3K/Akt signaling cascade, which promotes cell survival in many types of cancer. However, our results suggest that PAR1-induced cell survival is independent of

Akt activation, but occurs through the upregulation of Bcl-xL. Although both Bcl-2 and Bcl-xL prevent the release of cytochrome $c$ from the mitochondria, thereby blocking apoptosis, recent studies have indicated that Bcl-xL may play a more crucial role in prostate cancer cell antiapoptosis mechanism than Bcl-2. Suppression of Bcl-xL by oligonucleotides, but not Bcl-2, rendered cells more sensitive to induction of apoptosis [Lebedeva et al., 2000]. It has also been reported that over-expression of $\mathrm{Bcl}-\mathrm{xL}$ by transfection protected prostate cancer cells from the PI3K-specific inhibitor LY294002induced apoptosis [Yang et al., 2003]. Likewise, prostate cancer cells that have been exposed to exogenous IL-6 become resistant to chemotherapy due to the overexpression of Bcl-xL and not Bcl-2 [Pu et al., 2004]. Thus, Bcl-xL expression may be the crucial protein in promoting prostate cancer cell survival in the absence of PI3K/Akt signaling pathway.

In this study, we have shown that stimulation of PAR1, which is over-expressed in prostate cancer, plays an important role in prostate cancer cell survival through the activation of the $\mathrm{NF} \kappa \mathrm{B}$ signaling pathway (Fig. 9). This resulted in the increase production of IL- 6 and IL- 8 in prostate cancer cells, which have been implicated in the development of drug resistance and

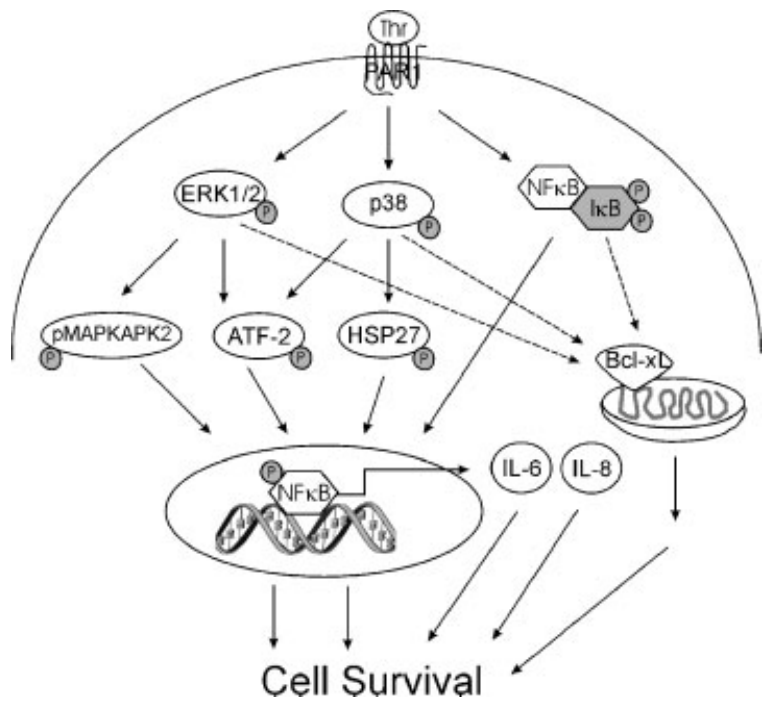

Fig. 9. Schematic representation of PAR1-induced signal transduction in prostate cancer. Activation of PAR1 by either thrombin or TRAP6 resulted in increased NFKB p65 subunit DNA binding activity. This resulted in upregulation of cytokine productions in prostate cancer. The p38 and ERK1/2 signaling cascades were also activated by PAR1. These pathways may work together to induce prostate cancer cell survival through the expression of $\mathrm{BCl}-\mathrm{xL}$. 
tumorigenesis. Furthermore, induction of PAR1 signaling attenuated cytotoxic drug-induced apoptosis through the up-regulation of Bcl-xL. Because thrombin, the ligand for PAR1 is readily available in the serum of prostate cancer patients, its ability to activate PAR1 may contribute to prostate cancer progression and evasion of apoptosis. In recent years, $\mathrm{NF} \kappa \mathrm{B}$ inhibitors have been developed extensively since dysregulation of $\mathrm{NF} \kappa \mathrm{B}$ signal has been implicated in many types of malignancies. Inhibition of the PAR1-thrombin interaction may contribute to the attenuation of $N F \kappa B$ signaling pathway and, therefore, may be beneficial to the management of the disease.

\section{ACKNOWLEDGMENTS}

We thank Chris Chay, Linda Kalikin, and Karen Giles for their useful comments and assistance in preparation of the article.

\section{REFERENCES}

Budunova IV, Perez P, Vaden VR, Spiegelman VS, Slaga TJ, Jorcano JL. 1999. Increased expression of p50-NFkappaB and constitutive activation of NF-kappaB transcription factors during mouse skin carcinogenesis. Oncogene 18:7423-7431.

Castro P, Xia C, Gomez L, Lamb DJ, Ittmann M. 2004. Interleukin-8 expression is increased in senescent prostatic epithelial cells and promotes the development of benign prostatic hyperplasia. Prostate 60:153-159.

Chalmers CJ, Balmanno K, Hadfield K, Ley R, Cook SJ. 2003. Thrombin inhibits Bim (Bcl-2-interacting mediator of cell death) expression and prevents serum-withdrawalinduced apoptosis via protease-activated receptor 1 . Biochem J 375:99-109.

Chay CH, Cooper CR, Gendernalik JD, Dhanasekaran SM, Chinnaiyan AM, Rubin MA, Schmaier AH, Pienta KJ. 2002. A functional thrombin receptor (PAR1) is expressed on bone-derived prostate cancer cell lines. Urology 60: 760-765.

Coughlin SR. 1999. How the protease thrombin talks to cells. Proc Natl Acad Sci USA 96:11023-11027.

Deocampo ND, Huang H, Tindall DJ. 2003. The role of PTEN in the progression and survival of prostate cancer. Minerva Endocrinol 28:145-153.

Dhanasekaran SM, Barrette TR, Ghosh D, Shah R, Varambally S, Kurachi K, Pienta KJ, Rubin MA, Chinnaiyan AM. 2001. Delineation of prognostic biomarkers in prostate cancer. Nature 412:822-826.

Even-Ram SC, Maoz M, Pokroy E, Reich R, Katz BZ, Gutwein P, Altevogt P, Bar-Shavit R. 2001. Tumor cell invasion is promoted by activation of protease activated receptor-1 in cooperation with the alpha vbeta 5 integrin. J Biol Chem 276:10952-10962.

Hardin J, MacLeod S, Grigorieva I, Chang R, Barlogie B, Xiao H, Epstein J. 1994. Interleukin-6 prevents dexamethasone-induced myeloma cell death. Blood 84:30633070 .
Huang YQ, Li JJ, Hu L, Lee M, Karpatkin S. 2001. Thrombin induces increased expression and secretion of VEGF from human FS4 fibroblasts, DU145 prostate cells and CHRF megakaryocytes. Thromb Haemost 86:10941098.

Je JH, Lee JY, Jung KJ, Sung B, Go EK, Yu BP, Chung HY. 2004. NF-kappaB activation mechanism of 4-hydroxyhexenal via NIK/IKK and p38 MAPK pathway. FEBS Lett 566:183-189.

Kang KW, Choi SY, Cho MK, Lee CH, Kim SG. 2003. Thrombin induces nitric-oxide synthase via Galpha12/ 13-coupled protein kinase C-dependent I-kappaBalpha phosphorylation and JNK-mediated I-kappaBalpha degradation. J Biol Chem 278:17368-17378.

Karin M, Cao Y, Greten FR, Li ZW. 2002. NF-kappaB in cancer: From innocent bystander to major culprit. Nat Rev Cancer 2:301-310.

Kaur J, Woodman RC, Kubes P. 2003. P38 MAPK: Critical molecule in thrombin-induced NF-kappa B-dependent leukocyte recruitment. Am J Physiol Heart Circ Physiol 284:H1095-H1103.

Kim SJ, Uehara H, Karashima T, McCarty M, Shih N, Fidler IJ. 2001. Expression of interleukin-8 correlates with angiogenesis, tumorigenicity, and metastasis of human prostate cancer cells implanted orthotopically in nude mice. Neoplasia 3:33-42.

Kohli M, Fink LM, Spencer HJ, Zent CS. 2002. Advanced prostate cancer activates coagulation: A controlled study of activation markers of coagulation in ambulatory patients with localized and advanced prostate cancer. Blood Coagul Fibrinolysis 13:1-5.

Koksal IT, Dirice E, Yasar D, Sanlioglu AD, Ciftcioglu A, Gulkesen KH, Ozes NO, Baykara M, Luleci G, Sanlioglu S. 2004. The assessment of PTEN tumor suppressor gene in combination with Gleason scoring and serum PSA to evaluate progression of prostate carcinoma. Urol Oncol 22:307-312.

Lebedeva I, Rando R, Ojwang J, Cossum P, Stein CA. 2000 Bcl-xL in prostate cancer cells: Effects of overexpression and down-regulation on chemosensitivity. Cancer Res 60: 6052-6060.

Leu CM, Wong FH, Chang C, Huang SF, Hu CP. 2003. Interleukin-6 acts as an antiapoptotic factor in human esophageal carcinoma cells through the activation of both STAT3 and mitogen-activated protein kinase pathways. Oncogene 22:7809-7818.

Lidington EA, Haskard DO, Mason JC. 2000. Induction of decay-accelerating factor by thrombin through a protease-activated receptor 1 and protein kinase Cdependent pathway protects vascular endothelial cells from complement-mediated injury. Blood 96:2784-2792.

Lind SE, Caprini JA, Goldshteyn S, Dohnal JC, Vesely SK, Shevrin DH. 2003. Correlates of thrombin generation in patients with advanced prostate cancer. Thromb Haemost 89:185-189.

Liu J, Bastian M, Kohlschein P, Schuff-Werner P, Steiner M. 2003. Expression of functional protease-activated receptor 1 in human prostate cancer cell lines. Urol Res 31:163-168.

Lu T, Burdelya LG, Swiatkowski SM, Boiko AD, Howe PH, Stark GR, Gudkov AV. 2004. Secreted transforming growth factor beta2 activates NF-kappaB, blocks apoptosis, and is essential for the survival of some tumor cells. Proc Natl Acad Sci USA 101:7112-7117. 
Maragoudakis ME, Tsopanoglou NE, Andriopoulou P. 2002. Mechanism of thrombin-induced angiogenesis. Biochem Soc Trans 30:173-177.

Marin V, Farnarier C, Gres S, Kaplanski S, Su MS, Dinarello CA, Kaplanski G. 2001. The p38 mitogenactivated protein kinase pathway plays a critical role in thrombin-induced endothelial chemokine production and leukocyte recruitment. Blood 98:667-673.

Ming XF, Barandier C, Viswambharan H, Kwak BR, Mach F, Mazzolai L, Hayoz D, Ruffieux J, Rusconi S, Montani JP, Yang Z. 2004. Thrombin stimulates human endothelial arginase enzymatic activity via RhoA/ROCK pathway: Implications for atherosclerotic endothelial dysfunction. Circulation 110:3708-3714.

Mitsui H, Maruyama T, Kimura S, Takuwa Y. 1998. Thrombin activates two stress-activated protein kinases, c-Jun N-terminal kinase and p38, in HepG2 cells. Hepatology 27:1362-1367.

Nierodzik ML, Kajumo F, Karpatkin S. 1992. Effect of thrombin treatment of tumor cells on adhesion of tumor cells to platelets in vitro and tumor metastasis in vivo. Cancer Res 52:3267-3272.

Palayoor ST, Youmell MY, Calderwood SK, Coleman CN, Price BD. 1999. Constitutive activation of IkappaB kinase alpha and NF-kappaB in prostate cancer cells is inhibited by ibuprofen. Oncogene 18:7389-7394.

Pu YS, Hour TC, Chuang SE, Cheng AL, Lai MK, Kuo ML. 2004. Interleukin-6 is responsible for drug resistance and anti-apoptotic effects in prostatic cancer cells. Prostate 60:120-129.

Rahman A, True AL, Anwar KN, Ye RD, Voyno-Yasenetskaya TA, Malik AB. 2002. Galpha(q) and Gbetagamma regulate PAR-1 signaling of thrombin-induced NF-kappaB activation and ICAM-1 transcription in endothelial cells. Circ Res 91:398-405.

Raj GV, Sekula JA, Guo R, Madden JF, Daaka Y. 2004. Lysophosphatidic acid promotes survival of androgeninsensitive prostate cancer PC3 cells via activation of NFkappaB. Prostate 61:105-113.

Rubin MA, Dunn R, Strawderman M, Pienta KJ. 2002. Tissue microarray sampling strategy for prostate cancer biomarker analysis. Am J Surg Pathol 26:312-319.

Shimada K, Nakamura M, Ishida E, Kishi M, Konishi N. 2003. Roles of p38- and c-jun NH2-terminal kinase- mediated pathways in 2-methoxyestradiol-induced p53 induction and apoptosis. Carcinogenesis 24:1067-1075.

Shukla S, MacLennan GT, Fu P, Patel J, Marengo SR, Resnick MI, Gupta S. 2004. Nuclear factor-kappaB/p65 (Rel A) is constitutively activated in human prostate adenocarcinoma and correlates with disease progression. Neoplasia 6:390-400.

Suh J, Payvandi F, Edelstein LC, Amenta PS, Zong WX, Gelinas C, Rabson AB. 2002. Mechanisms of constitutive NF-kappaB activation in human prostate cancer cells. Prostate 52:183-200.

Vu TK, Hung DT, Wheaton VI, Coughlin SR. 1991. Molecular cloning of a functional thrombin receptor reveals a novel proteolytic mechanism of receptor activation. Cell 64:1057-1068.

Walz DA, Fenton JW. 1994. The role of thrombin in tumor cell metastasis. Invasion Metastasis 14:303-308.

Wojtukiewicz MZ, Tang DG, Ciarelli JJ, Nelson KK, Walz DA, Diglio CA, Mammen EF, Honn KV. 1993. Thrombin increases the metastatic potential of tumor cells. Int $\mathrm{J}$ Cancer 54:793-806.

Yang CC, Lin HP, Chen CS, Yang YT, Tseng PH, Rangnekar VM. 2003. Bcl-xL mediates a survival mechanism independent of the phosphoinositide 3-kinase/Akt pathway in prostate cancer cells. J Biol Chem 278: 25872-25878.

Yin YJ, Salah Z, Grisaru-Granovsky S, Cohen I, Even-Ram SC, Maoz M, Uziely B, Peretz T, Bar-Shavit R. 2003. Human protease-activated receptor 1 expression in mali gnant epithelia: A role in invasiveness. Arterioscler Thromb Vasc Biol 23:940-944.

Yuan H, Liddle FJ, Mahajan S, Frank DA. 2004. IL-6induced survival of colorectal carcinoma cells is inhibited by butyrate through down-regulation of the IL- 6 receptor. Carcinogenesis 25:2247-2255.

Zain J, Huang YQ, Feng X, Nierodzik ML, Li JJ, Karpatkin S. 2000. Concentration-dependent dual effect of thrombin on impaired growth/apoptosis or mitogenesis in tumor cells. Blood 95:3133-3138.

Zerbini LF, Wang Y, Cho JY, Libermann TA. 2003. Constitutive activation of nuclear factor kappaB p50/ p65 and Fra-1 and JunD is essential for deregulated interleukin 6 expression in prostate cancer. Cancer Res 63:2206-2215. 